Florida International University FIU Digital Commons

$4-1982$

\title{
A study to identify the nutritional problems in the elementary school population in the Republic of Venezuela
}

Luis Alonso Calatrava

Florida International University

DOI: $10.25148 /$ etd.FI14052536

Follow this and additional works at: https://digitalcommons.fiu.edu/etd

Part of the Hospitality Administration and Management Commons

\section{Recommended Citation}

Calatrava, Luis Alonso, "A study to identify the nutritional problems in the elementary school population in the Republic of Venezuela" (1982). FIU Electronic Theses and Dissertations. 1972.

https://digitalcommons.fiu.edu/etd/1972 


\section{A STUDY TO IDENTIFY}

THE NUTRITIONAL PROBLEMS IN THE ELEMENTARY SCHOOL STUDENT POPULATION IN THE REPUBLIC OF VENEZUELA

BY

LUIS ALONSO CALATRAVA

A THESIS SUBMITTED IN PARTIAL FULFILLMENT OF THE REQUIREMENTS FOR THE DEGREE OF MASTER OF SCIENCE IN HOTEL AND FOOD SERVICE MANAGEMENT AT FLORIDA INTERNATIONAL UNIVERSITY

COMMITEE IN CHARGE:

PROFESSOR LENDAL H. KOTSCHEVAR, CHAIRPERSON PROFESSOR THEODORE WHITE APRIL 1982 
TO PROFESSORS:

LENDAL H. KOTSCHEVAR

AND

THEODORE WHITE

This thesis, having been approved in respect to form and mechanical execution, is referred to you for judgement upon its substantial merits.

DEAN GERALD W. LATTIN

SCHOOL OF HOSPITALITY

MANAGEMENT

The thesis of Luis Alonso Calatrawa is approved.

PROFESSOR LENDAL H. KOTSCHEVAR

PROFESSOR THEODORE WHITE

Date of Examination

APRIL 1982 
A STUDY TO IDENTTFY AND EVALUATE THE EXTSTJNG NUTRITIONAL PROBLEMS IN THE STUDENT POPULATION AT THE ELEMENTARY SCHOOL LEVEL IN THE REPUBLIC OF VENEZUELA.

\begin{abstract}
A THESIS PRESENTED TO THE HOSPITALITY SCHOOL OF THE FLORIDA INTERNATIONAL UNIVERSITY.
\end{abstract}

IN PARTIAL FULFILLMENT OF THE REQUIREMENTS FOR THE MASTER'S DEGREE IN HOTEL MANAGEMENT.

BY

LUIS ALONSO CALATRAVA

APRIL， 1982 


\section{DEDICATION}

I wish to express my gratitude to the Fundación Gran Mariscal de Ayacucho, for giving me the opportunity to pursue my professional goals by providing with the scholarship that enabled me to study in the United States, thus helping me become a professional that will be able to contribute to the development of Venezuela.

I also want to give my special gratitude to my family, who gave the moral support during this new experience in my 1 ife, and to my Venezuelan classmates. 


\section{INTRODUCTION}

The nutritional needs of the school child are not being taken into consideration when the programs geared to solve them are planned and implemented, as likewise a rational and efficient utilization is not being done of the resources assigned to those programs. The increase in the student population in the next coming years will emphasize the need to find solutions that will guarantee the satisfaction of nutritional demands in a more efficient manner that will assure the healthy intellectual and physical development of children, who are the most valuable resource a country can have. 
I. THE PROBLEM AND ITS SETTING

The Statement of the Problem
The Statement of the Subproblem
The Hypothesis
The Delimitations
The Definition of Terms

Abbreviations Used in this Study

Assumption

The Importance of the Study

II. THE REVIEW OF THE RELATED LITERATURE

A Historical Overview

Nutritional Problem Overview

Economic Overview

Instituto Nacional de Nutrición Overview

Analysis of the Present Systems for the School Children Care Program and their Structure

III. FIELD RESEARCH

IV. SYSTEM DESIGN

V. THE DATA AND THE TREATMENT OF THE DATA

VI. THE TEST OF THE HYPOTHESIS 
VII. CONCLUSION AND RECOMMENDATIONS

IX . BIBLIOGRAPHY 
THE PROBLEM AND ITS SETTING

THE STATEMENT OF THE PROBLEM.

The purpose of this research is to identify and evaluate the nutritional problems that exist in the student population at the elementary school level in the Republic of Venezuela and to develop a system that will make it possible to deliver a more adequate diet to this population, with a greater fulfillment of their nutritional needs.

\section{SUBPROBLEMS}

1. The first subproblem is to determine the nutritional needs of elementary school children and to confront: them with the present fulfillment of those needs that those children are receiving through the government programs for child nutrition.

2. The second subproblem is to identify and analize the organization of the present nutritional programs designed for elementary school children and to compare them with a single program that will centralize all efforts through the implementation of an effective program that will truly satisfy the nutritional needs of the aforementioned population.

3. The third subproblem is to identify and analize the structure of the legal and governmental framework that presently regulates the functioning of nutritional programs and to point out in what areas the aforementioned legal and governmental structures are interfering with the development of a better 
performance of those programs, due to specific legal and governmental limitations that have been imposed on them.

4. The fourth subproblem is to analyze how the economic and human resources assigned to elementary school nutritional programs are being used and point out where these same resources can be more rationally used, at the same time as new sources of economic aid are obtained that will allow these programs to reach a greater segment of the population receiving those services. 
THE HYPOTHESIS :

1. The programs designed to make up for the nutritional defficiencies found in the elementary school student population are not fulfilling their goals qualitatively in respect to an evaluation of the real nutritional needs of those children.

2. The programs designed to cater to the nutritional defficiencies found in the elementary school student population are not fulfilling their objectives quantitatively in terms of the number of children in the school population that are receiving those services.

3. To the extent that the governmental and legal framework regulating the operation of nutritional programs for the student population is improved, these improvements will result in a more efficient implementation of the governmental and legal provisions, which will enable us to satisfy the real nutritional needs of said population.

4. The systems created for the administration and execution of nutritional programs for school children do not foster a rational and efficient utilization of the economic and human resources assigned to those programs, nor do they promote efficient methods of supervision for the operation of said programs and evaluation of their results. 
THE DELIMITATION:

- This research does not intend to find a complete solution to the nutritional problems presented by the elementary school student population.

- This research does not intend to propose a legal basis for the implementation of a newly designed system for the solution of nutritional problems found in elementary school children.

- The system proposed by this study will be limited by the extent of the assignment of economic and human resources that will allow the implementation of said system.

- This research will be limited by the extent of the interest it might be able to awaken among the different political sectors of the Venezuelan society.

- This research does not intend to go in depth in the study of the different diets which could be provided to elementary school children.

- This research does not intend to take into account the particular situation of each Venezuelan region, since the proposed system is geared for those cases in which central kitchens are the best means for the preparation of meals for the school population. 
Definitions.

Gaceta Oficial: official publication by the Venezuelan government of all the decisions made by the $\mathrm{Na}-$ tional Government and other state agencies.

Arepa:

basic staple of the Venezuelan diet made with corn meal.

Ecónoma:

supervisor in charge of the Comedores Escolares.

Corporación de Mercadeo Agricola: government institute for the marketing and distribution of food products at a national level.

Note: List of definitions is relatively short as most of the numerous terms used in this research have been translated and/or explained in the work itself for the convenience of the readers. 
Abbreviations.

CORDIPLAN: Coordinación de Planificación [Planning Coordination office]. - government office that coordinates the execution of the Venezuelan National Plan.

I.N.N.: $\quad$ Instituto Nacional de Nutrición [National Institute of Nutrition].

M.E.: $\quad$ Ministerio de Educación [Ministry of Education].

M.S.․․․․: $\quad$ Ministerio de Salud y Asistencia Social [Ministry of Helath and Welfare].

$\underline{P} . \underline{L} .: \quad \quad \quad$ Producto Lácteo $[$ Milk Product].

PROALIFAM: Producto Alimenticio Familiar [Family Nutritional Product J. 
The first assumption. The first assumption is that the school population with nutritional problems at the school level will incrrease in the near future.

The second assumption. The second assumption is that the Venezuelan government is the only one that has the necessary means to face up to the nutritional problems of elementary school children and put forth solutions to these problems.

The third assumption. The third assumption is that the centralization of efforts will be the best way to achieve a more efficient use of the human and economic resources and of the available foodstuffs.

The fourth assumption. The fourth assumption is that the change in the organizational structures at the governmental level proposed by this study will bring, as a result, a greater knowledge and more effective control of Venezuelan nutritional problems found in elementary school children.

The fifth assumption. The fifth assumption is that this study will not be representative nor will it propose solutions to the nutritional problems of the whole population of school children in Venezuela. 
The importance of the human factor in the development of all countries is a well-known fact, as is the importance of the younger population as the basis for the future develonment of society.

In the case of Venezuela the importance of the younger sector is even more relevant since Venezuela is characterized by a high percentage of population under 15 years of age, who will in time become the main source of support for the development of the country. That is why it is so important to guarantee a minimum nutritional intake that will foster a healthy physical as well as intellectual development of the young population of Venezuela.

As established by the Venezuelan Constitution, every child has the right to education and to adequate nutrition provided by the corresponding legal person, or, in the absence of that person, by the government, as expressed in this respect by the Ley Tutelar del Menor [Child Protection Law], whose article number one, ordinales [subarticles] I. and II, reads as follows:

Ordinal I: This law has as an objective the protection and welfare of the child and to establish the right the child has to live in conditions that will allow him or her to reach a normal biological, mental, moral and social development. To this effect the state will provide all means and conditions necessary. 
The main result of the execution of this program would be to enable teachers to develop the intellectual and physical potential of the children under their care. As pointed out by Ex-President Lyndon B. Johnson, who was a Texas school teacher in his youth, "I know what it is to teach children who are listless and tired because they are hungry, and realize the difference a decent meal can make in the lives and attitudes of school children." 


\section{THE RELATED LITERATURE}

A Historical Overview.

In the year 1949 the National Institute of Nutrition was created by Presidential Decree No. 320 on the 11 th of November, as published in the Gaceta Oficial No. 23,077, thus culminating the efforts that had been made to that purpose, in view of the need to lessen the nutritional problems that a populous sector of the Venezuelan society was suffering.

We could say that its forerunners go back to the year 1895 , when Dr. Yanuel A. Diez published his first study on this subject entitled "Tratado de Alimentación" [Treatise on Nutrition], which was followed by a similar one written by Dr. Augusto Ortega published in 1899.

At the beginning of this century, Dr. Fernando Boulet founded in Petare a establishment for the free distribution of meals, Sopa Popular [Soup for the People], and in $1936 \mathrm{Dr}$. Francisco Antonio Rísquez, in collaboration with Dr. Armando González Puccini, implemented a service of Sopa Popular of a more advanced type, on account of the celebration of the First Sanitary Cruzade in the country. This establishment gave origen to the Comedores Populares [People's Diners], which started springing up in several neighborhoods in Caracas, such as La Pastora, Palo Grande, Puente Sucre and Prado de María. 
Following these events, the nutritional problem started to be taken into consideration by the official sector and it is precisely in 1938 when the Federal Executive dictated the first measures towards the creation of the "Servicio de Alimentacion Nacional" [National Service of Meals], and set up a Comedor Popular [People's Diner, see above] in the port city of La Guiara on November the 12 th, 1938 and another one in Caracas on May 14th, 1939 at the corner of the former Plaza de España. These Comedores are the "starting point for the final integration of the National Institute of Nutrition," whose structure would be finally devised later on, preceisely in 1969, after several reorganizing measures which had become necessary after accumulating experiences and having delved deep into the study of nutritional problems. The events that took place during that stretch of time are the following:

a) In 1942 the "Nutrition Section" ['Sección de Nutrición"] was founded as a dependency of the Dirección de Salud Pública [Public Health Office] of the Ministerio de Sanidad y Asistencia Social [Ministry of Health and Welfare], in which there had been a Commission on Nutrition since August of the previous year. The aforementioned Sección was subdivided further into three Servicios: 1) Service for Socio-economic Research of the problem (nutritional surveys); 2) Educational and Publicity Campaign and 3) Service of Foods and Beverage. 
b) On July the 1st, 1944, the Nutrition Section was merged with other Public Health office departments and a new Division was created: the Pharmacy and Dietetics Division [División de Bromatología y Farmacia ].

c) In 1945 the "Patronato Nacional de Comedores Escolares" [National Office for School Cafeterias] was established.

d) On October $24 \mathrm{th}, 1946$, by Decree no. 420, the Instituto Pro-Alimentación Popular [Institute for People's Nutrition] was founded with an autonomous charter, which absorbed the functions of the former Nutrition Section which had been merged into the Pharmacy and Dietetics Division, concentrating in the Institute all the activities which were being performed by other dependencies of the division. The Secretaria del Comité de Enlace de la F.A.O. [Office of the Committee of Liaison with the F.A.O.] was also attached to the Institute, with the goal in mind of maintaining a close relationship with that important insternational organization.

e) In July, 1947, the Comedor Popular at the Plaza de España came under the administration of the Instituto Pro-Alimentacion Popular, and towards the end of 1948 there were already 16 Comedores Populares in service.

f) Tn 1949 a project or re-organization was devised and on the 11 th of November of that year the NATIONAL INSTITUTE OF NUTRITION was founded, which would replace the Instituto Pro-Aljmentación Popular. Soon after it would start to consolidate its organizational base which enabled it to structure programs of importance and to expand the range of its activities. 
In October, 1950, the School of Nutrition and Dietetics [Escuelas de Nutricionistas $\underline{y}$ Dietistas] was established, and in February, 1952, the construction of the Edificio Sede [Headquarters Building] was started at the Esquina El Carmen, whose inauguration was to take place on the 25 th of November the next year.

By 1956 , the administrative structure [Dirección General] of the Institute was comprised by two great divisions: Nutrition and Administration. The first one encompassed the following services: Biochemistry (Dietetics and Food Technology), Physiology, Scientific Nutrition, Social Nutrition, Dietetics and Control of Nutrition in Collective Communities, Diabetes and the Conse jo Informativo de Educación Alimenticia [Council on Educational

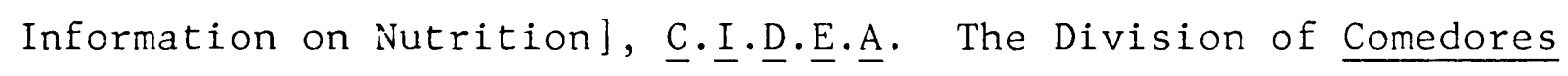
Populares became an adjunct to the Division of Nutrition. On February 1st, 1958, the Institute experienced the first transformation of its structure under Dr. Armando Castillo Plaza. Other innovations took place in 1959 and in 1964 and finally, in 1969, the Institute took over the functions of the National office for Comedores Populares, which was merged into the Institute on January 1st, 1969, in accordance with the provisions of the National Institute of Nutrition Bill [Ley del Instituto Nacional de Nutrición], passed into law by the National Congress on August 30th, 1968. Its functional reorganization, however, began on April 1st, 1969, with the designation of a new Executive Director.

The National Institute of Nutrition came into being upon passage of the bill that sponsored j.t on September 12 th, 1968 . 
It is an autonomous institute, a legal entity with its own funds, attached to the Ministry of. Health and Welfare, with headquarters in Caracas.

Ever since its foundation to the present day, the $\underline{T} \cdot \underline{N} \cdot \underline{N}$. has been in charge of everything regarding blanning, organizing, executing and supervising the different nutritional programs in Venezuela. 
Nutritional Problem Overview.

Venezuela is still today a country that is highly vulnerable to problems due to undernourishment, as $42 \%$ of its population is under 15 years of age and its birth rate for the year 1979 was 36.6 live births per thousand. On the other hand, life expectancy at the present time is 68 years, which points towards an adult population susceptible to cardiovascular disease and other illnesses that are related to nutritional problems.

For example, in the year 1978 deaths due to cardiovascular disease comprised $20.7 \%$ of all deaths, being highly linked to nutrition. In children under 5 years of age, nutritional deficiency is one of the most serious problems, which together with low weight at birth endangers the child's chances for survival and retards his development. We can observe that four of the main causes of deaths in the 1 to 4 age bracket (pneumonia, gastroenteritis and other diarrheal conditions, German measles, avitaminosis and other nutritional deficiencies) are highly co-related with the nutritional state. It is important to point out that deaths due to avitaminosis and other nutritional deficiencies have decreased by $45 \%$, that is, from 10.3 in 1973 to 5.9 in 1978 in all age groups. Nevertheless, it is the children under 2 years of age that are most affected: $54.3 \%$ of all deaths due to avitaminosis and other nutritional deficiencies belong to this age group.

In respect to mortality trends, the studies on death rate undertaken by the National Institute of Nutrition through its Epidemiological Program in 25 communities in the country where 2,573 
children under 15 years of age were examined, revealed that $33.11 \%$ were undernourished according to age-hejght relationship, and $20.67 \%$ according to age-weight relationship.

As to medical visits in rural communities, a high percentage of these have as a reason nutritional anemias, whereas endemic goiter is more frequent in mountainous regions, where it can reach percentages of up to $40 \%$.

An analysis of the agricultural sector shows a deficit in the production of cereals, beans, peas, powdered milk and fats, a fact that makes Venezuela dependent on foreign food supplies for more than $50 \%$ of its needs. Cereals contribute around $40 \%$ of the total intake of available calories, while it could be assumed that there is a high consumption of sugar, in view of j.ts obvious increase, which from 38 Kg-person/year in 1970 has jumped to $50 \mathrm{Kg}$-person/year in 1977. For this last year, according to the Hojas de Balance [Caloric Charts], the availability of calories and pro-teins was 2,693 calories and 75.4 grams of proteins, statistics that were considered satisfactory.

Surveys carried out in Venezuela between 1949 and 1978 reflect the caloric underconsumption, especially in the lower socio-economic groups. It is worthy to point out that according to the Survey of Homes (1979), $57.55 \%$ of all homes are comprised by 5 or more members and that out of those, $46.58 \%$ make 1 ess than 2,000 Bolivares per month, an income which has been considered by Cordiplan as the minimum subsistence salary. 
On the other hand, $t \therefore \equiv \pm . \because .8$. Cetermined in 1980 that a family of 3 needs Bs. 693.00 a $\ldots:-z$ for Ezod expenses, a family of 6 Bs. $1,368.00$, and a famil $\because=\equiv 10$ $\Xi \equiv .2,310.00$.

It is known that the - $\sum_{i e n i=}$ anditions of the environment have an effect on the nut:: : innal $\equiv$ ate as they interfere with the proper biological uti:-こ三こiこ? $=\sum$ nutrients and precipitate undernourishment clinical $\equiv-\vdots 5: \vdots=\vdots$ inical syndromes. Hence the high incidence of diarrhe :- $=\dot{s}$ se $\equiv \equiv s$ and parasytic illness, which are considered public hea: :- =ro:

In respect to food $h: \equiv \equiv \equiv . e$ in $\because$ enezuela, the institutions responsible for regulatic: $\equiv \equiv: d \equiv z \equiv$-dards of quality have focused

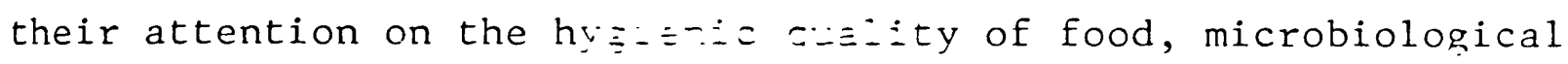
safety and contamination : :- =:21. $\therefore$ E Far as the nutritional auali-

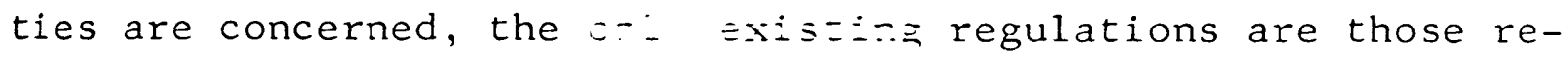
lated to addition of vita-.-s. $s \Sigma_{\Sigma}=s$, protein and other nutrients to foods for special diet $\equiv . \equiv \ni l e \equiv \equiv l t$, wheat flour, fruit juices and margarine.

Human resources in $t-\vdots \equiv=2 a=\sum$ nutrition is essential, so much in the processes of $: \because: ニ ニ ニ ミ: a$. consumption and utilization of foodstuffs as in the $F-\equiv-\cdots+n g=\equiv$ policies to guarantee the

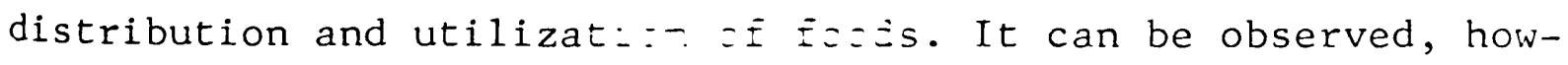
ever, that in the area of - - $\equiv$ n $r \equiv \equiv z u$ urces there is not a systematic and continuous plan $0 \equiv=\equiv \because \boxminus l \cong=-\equiv n t$ of these important resources. 
necessary to eliminate the distribution of soy-enriched meals, since it performed the same function as the aforementioned services and is not produced in the country.

Similarly, it was necessary to eliminate the service of "A Glass of Milk for the School Child," which was replaced by Lactovisoy, which has a higher nutritional value, a lower price and is easier to preserve and distribute.

The "Family Protection" Sub-Program was cut by 5.4 million dollars, making it necessary to reduce the PROALIFAM II by 1.1 million, and merging the PROALIFAM I and III into one service, since they follow the same objective, being both reduced by 4.2 million dollars.

As can be observed, the Nutritional Protection Program is the one that has suffered the greatest budget cuts. The sub-program of Pre-School Care (Protección al Preescolar), the subject of this study, is comprised by this program and has suffered a reduction of 9.2 million dollars, a sum that represents a full $49.4 \%$ of the total reduction of the whole program.

Due to this considerable decrease in funds it is imperative to find the rational ways and means to decrease wasteful expenditure, make the most out of available resources, and find new sources of funds which will enable this sub-program not only to be partially supported but the increase the service rendered to school children. 
Instituto Nacional de Nutrición Overview.

As mentioned before, the Instituto Nacional de vutrición came into being upon the passing of the legislation that sponsored it on September 12th, 1968. It is an autonomous institution, a legal entity with funding of its own, attached to the Ministry of Health and Welfare, with headquarters in Caracas.

Objectives.

It is the duty of the Instituto to implement the policies of the National Executive pertaining to nutrition and foods.

To render services in this field throughout the country.

To prevent, through education and research, problems related to nutrition in Venezuela.

Functions.

To plan nutritional programs provided by the Ministry of Health Services.

To study the nutritional content of foods.

To research the problems caused by nutritional deficiencies.

To plan the strategy against diseases caused by undernourishment .

To organize, maintain and manage the Comedores Populares.

To set the minimum standards for meals served in schools, welfare institutions and other of social character.

To organize educational campaigns of the specific subject of nutrition.

To train the technical personnel needed to implement nutrition programs.

To study and to take all measures necessary to improve the nutritional standards of the Venezuelan people. 
Legal Structure.

The Venezuelan Constitution, as previously mentioned, is the first in the country to establish a duty on the part of the State to provide a minimum of nourishment for those in the population younger than fifteen. This is the foundation for all legal regulations affecting the organizations and institutions involved in the fulfillment of the Constitutional order.

The National Congress of the Republic of Venezuela, only organization in the country empowered to make and approve legislation, entrusted the $\underline{I} \cdot \underline{N} \cdot \underline{N}$. with specific duties and functions which have been implemented since the date the law was passed.

Such functions are:

1) Research of nutritional problems in Venezuela; to foster, advise and contribute to nutritional research projects undertaken by teaching and welfare institution, and of public or private research projects, especially in the case of research projects with practical applications.

2) To advise the National Executive on matters pertaining to the formulation of national policies on the subject of nutrition and foods.

3) To plan and program services sponsored by the nutrition policy being developed.

4) To oversee the performance of all other organizations that carry out nutrition programs for grouds or collective communities.

5) To advise those organizations that so request on the planning of nutritional services. 
6) To train the ideal personnel for the execution of the programs sponsored the the Instituto.

7) To maintain a constant flow of public information at a national and international level on those programs it sponsors.

This law has determined that the $\underline{I} . \underline{N}$. N . be attached to the Ministry of Health and Welfare.

The I. $. \underline{N} . \underline{.}$, as established in its by-laws, regulates in turn all those programs of welfare in charge of the prevention and control of nutritional services carried out by several organizations that are managed by the Instituto. Among those programs. we can find the Comedores Escolares*, which are supervised by the Nutritional Division of Public Health. The regulations for the Comedores Escolares, effective since 1958, has established in its 57 articles all the provisions pertaining to the organization, management and control of the Comedores Escolares.

* Comedores Escolares is roughly equivalent to "School Cafeterias." 
Outline of the Venezuelan Government Structure in Relation to Nutritional Programs.

\section{VENEZUELAN CONSTITUTION}

$\begin{array}{ccc}\text { Fxecutive Branch } & \text { Legislative Branch } & \text { Judicial Branch } \\ \text { (President) } & \text { (Congress) } & \text { (Subreme Court) }\end{array}$

I.N.N. Ministry of Health
and Welfare

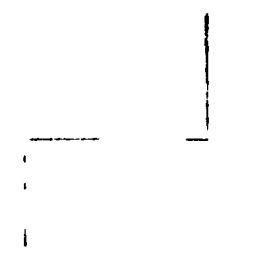

Hutrition and Public

Health Division

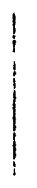

School Child Protection

Mational office of

Comedores Escolares [School Cafeterias]

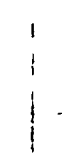

Niedores Escolares

- Program
School Snack

Program

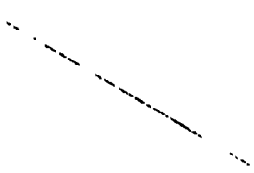

Lactovisoy

Prógram
"Glass of Milk" Program 

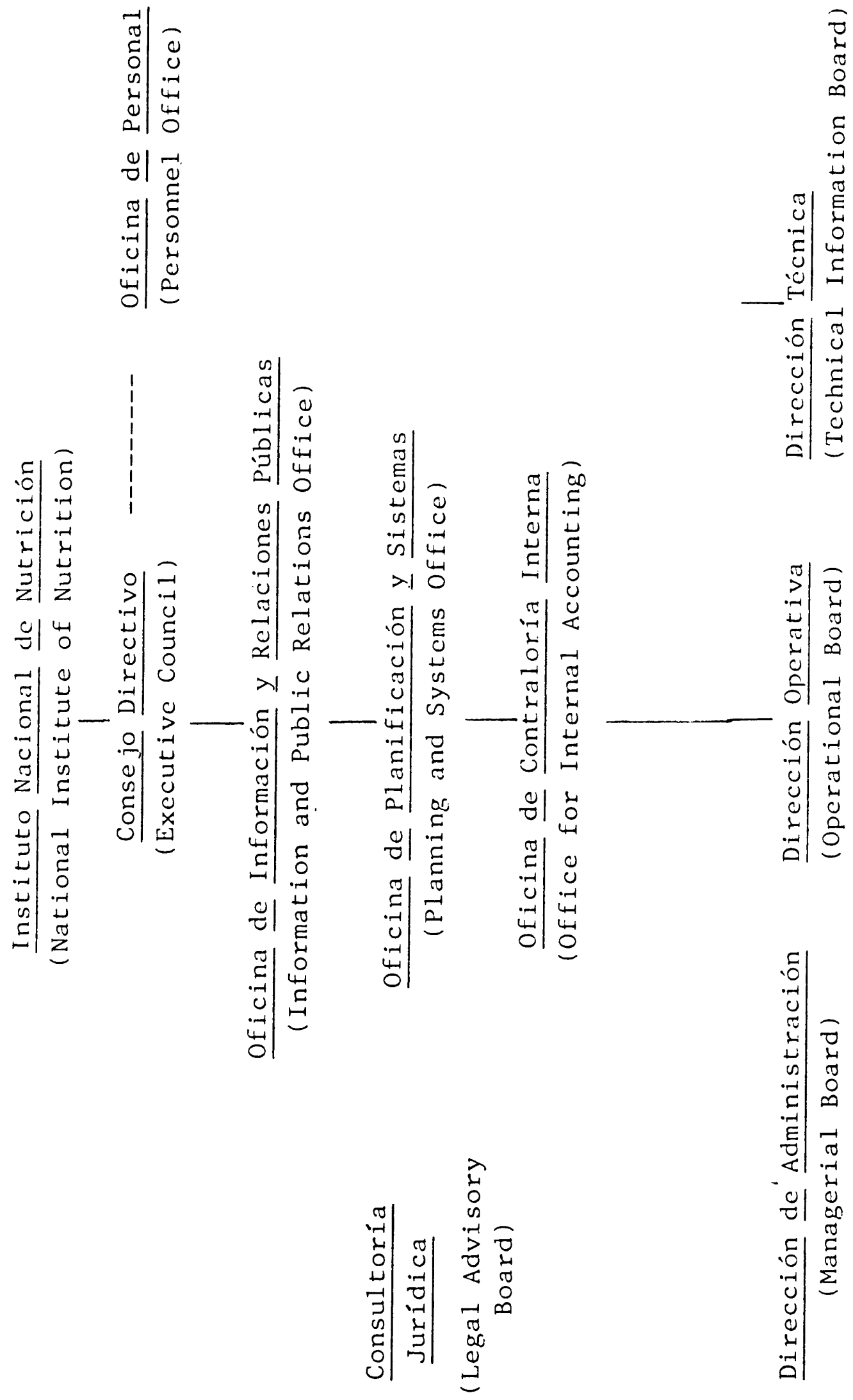
Objectives of Each Unit.

$$
\frac{\text { Conse jo Directivo }}{\text { (Executive Council) }}
$$

Ob jective:

To write the regulations for the execution of the nutritional policies set by the National Executive, of short, medium and long-range plans, as well as responsible for other matters pertaining the total fulfillment of the goals of the Instituto.

$$
\frac{\text { Oficina de }}{\text { (Information and Public }} \frac{\text { Información }}{\text { Relations }} \frac{\text { Relaciones }}{\text { Of́blicas }}
$$

Objective:

To circulate information through the mass media among workers and the community in general of the plans, programs and activities sponsored by the Instituto conducive to harmonious public relations for the Instituto Nacional de Nutrición.

$$
\frac{\text { Oficina de }}{\text { (Personnel }} \frac{\text { Personal }}{\text { Office) }}
$$

Objective:

The Personnel office is a consulting technical dependency attached to the Executive Counci1. In consists in three Departments, a Secretary's Office, a Legal Advisory Board, a Legal Negociations and Compromise Board [Junta de Avenimiento], a Tripartite Commission and a Commission's Office. 


\section{Oficina de Planificación y Sistemas \\ (Planning and Systems office)}

Ob jective:

To direct and coordinate short, medium and long-range planning and political strategies in the nutrition sector; to administer the annual budget, supervise data processing and the gathering of statistics and execution of research projects on organizational systems for the $\underline{I} . \underline{N} . \underline{N}$.

$$
\frac{\text { Oficina de }}{\text { (Office for } \frac{\text { Contraloria Interna }}{\text { Internal Accounting) }}}
$$

Objective:

To control and supervise the rational use of financial resources, in order to guarantee the ideal spending of $\underline{I} \cdot \underline{N} . \underline{N}$. finances.

$$
\frac{\text { Consultoria Juridica }}{\text { (Legal Advisory Board) }}
$$

Objective:

To council and assist the managerial and executive units of the $\underline{I} \cdot \underline{N} . \underline{N}$. on legal matters, according to the laws in force in the country.

$$
\frac{\text { Dirección de }}{\text { (Managerial Board) }}
$$

Objective:

To manage administrative and financial matters, as well as the rendering of the $\underline{I} \cdot \underline{N} \cdot \underline{N}$.'s general services according with the regulations and procedures established by the competent authorities. 


\title{
Dirección Operativa
}

(Operational Board)

Ob jective:

To carry out, throughout its several units, the $\underline{I} \cdot \underline{N} . \underline{N}$. plans and programs in order to achieve the objectives established.

\author{
Dirección Técnica \\ (Technical Information Board)
}

Objective:

To develop methods, procedures and practical applications of a technical nature; to do research on human nutrition; and to train its personnel and educate the Venezuelan people in the area of foods and nutrition. 
Adolescent Assistance Program (continuation)

Students assisted in Comedores who received special

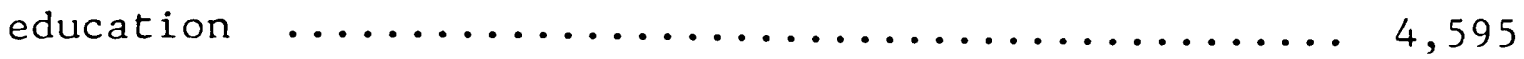

Family Nutrition Program [ Programa de Alimentación Familiar

(PROALIFAM)

Number of families assisted

30,090

Number of persons assisted

As mentioned before, this research has as a main objective to identify and evaluate the existing nutritional problems in the student population at the elementary school level in the Republic of Venezuela.

The elementary school student population according to studies carried out in 1980 shows the following results:

Total Number of Elementary School Students

State

Total for Venezuela

Federal District

Anzoategui

Apure

Aragua

Barinas

Bolivar

Carabobo

Cojedes

Falcón

Guarico

Lara

Mérida

Miranda

Monagas

Nueva Esparta

Portuguesa

Sucre Tota 1

$2,456,815$

299,684

123,689

41,149

137,293

61,502

117,277

166,442

24,881

99,191

78,026

160,996

80,285

206,645

74,961

30,019

78,158

108,693
Public Schools

$2,182,104$

228,630

114,720

39,914

119,565

59,642

107,782

147,371

24,601

91,947

75,703

148,754

75,010

153,683

73,105

29,038

74,719

104,501
Private Schools

274,711

71,054

8,969

1,235

17,728

1,860

9,495

19,071 280

7,244

2,323

12,242

5,275

52,962

1,846

981

3,439

4,192 
Total Number of Elementary School Students (Continuation)

$\begin{array}{lrrr}\text { Tachira } & 113,902 & 103,444 & 4,192 \\ \text { Trujillo } & 83,080 & 80,807 & 10,458 \\ \text { Yaracuy } & 55,086 & 52,403 & 2,683 \\ \text { Zulia } & 293,891 & 257,138 & 36,753 \\ \text { Amazonas District } & 8,793 & 6,816 & 1,977 \\ \text { Amacuro District } & 13,172 & 12,811 & 361\end{array}$

Elementary School Students

Classified by School Grade

$\begin{array}{cccccccc}\begin{array}{c}\text { School } \\ \text { Year }\end{array} & \begin{array}{c}\text { Total } \\ \text { Number }\end{array} & \text { First } & \text { Second } & \text { Shird } & \text { Fourth } & \text { Fifth } & \text { Sixth } \\ 79-80 & 2,456,815 & 550,411 & 461,596 & 433,897 & 395,084 & 335,821 & 280,006 \\ \% & 100.0 & 22.4 & 18.8 & 17.7 & 16.1 & 13.6 & 11.4\end{array}$

During the decade $70-80$, the annual rate of growth bears these results:

$\begin{array}{llll}\text { First Grade } & 3.9 \% & \text { Fourth Grade } & 3.5 \% \\ \text { Second Grade } & 2.5 \% & \text { Fifth Grade } & 4.1 \% \\ \text { Third Grade } & 3.8 \% & \text { Sixth Grade } & 4.9 \%\end{array}$

Total Number of Schools at a National Level, 79-80

$\begin{array}{lr}\text { Public } & 11,710 \\ \text { Private } & \frac{1,216}{12,926}\end{array}$

Total Number of Comedores Escolares [School Cafeterias ] Public Schools, 79-80 2,475 units

1) Student Population Assisted with Merienda Escolar [School Snack] at a National Level in 1980

$$
235,892
$$

2) Student Population assisted with soy-enriched milk product (Lactovisoy) at a National Level in 1980 
3) Student Population assisted through the "Glass of Milk" Program

("Vaso de Leche al Escolar) at a National Level in 1980

$$
203,330
$$

4) Student Population assisted through the Comedores Escolares

[School Cafeterias] Program at a National Level in 1980

$$
284,062
$$

At this point we will show the School Children Care Program [Protección al Estudiante]. This program comprises a series of sub-programs which are detailed as follows:

Merienda Escolar [School Snack]

Lactovisoy

Vaso de Leche al Escolar ["Glass of Milk"]

Comedores Escolares [School Cafeterias]

Analysis of the Present Systems for the School Children Care

Program and How They Are Structured:

Merienda Escolar [School Snack].

Objectives:

To distribute soy-enriched corn arepas having as a main goal to supply students from marginated zones with an additional source of calories that will help them fulfill their nutritional requirements.

Arepas supply approximately $12 \%$ of the calories required by a 9-year-old child.

Boundaries:

1) Physical Boundaries
a) Geographical Area
b) Storage Capacity
c) Production Capacity
d) Packing Capacity 
Continuation of Boundaries of the Merienda Escolar [School Snack] Sub-program of the School Children Care Program [Protección al Escolar], of Section (1) (Physical Boundaries):

e) Transportation Capacity

f) Distribution Capacity

g) Equipment Capacity

h) Budget

2) Abstract Boundaries

a) Management and Employees Competence and Abilities

b) Internal Quality Requirements

c) Governmental Regulations (External) Quality Requirements

Basic Product:

This program's basic product is the "arepa," which is made up of $92 \%$ corn meal plus $8 \%$ soy meal, to which some kind of filling is added, such as ham, cheese, margarine, mortadella et al.

Requirements to ioin the program:

School principals who are interested in establishing this service in their schools should send a letter to the Nutrition Unit Chief of the state in which the school is, and as soon as the letter is received a technical team will be sent to conduct a research on the number of students, facilities available, etc.

Should the result of their study be favorable, the school in question will be added to the School Snack Sub-Program [Merienda Escolar ].

The System:

This is a very simple system and is included here because it is being applied to some sectors of the student population. 
Preparation:

Arepas are prepared daily by mothers from the same community as where the school is located (mothers of the children receiving this service). Payment for their labor is by unit.

Distribution:

Daily delivery of the arepas is the responsibility of the teachers, who distribute them among all children in the school. The service is offered only on schools days.

Supervision:

All steps in the execution of the program are supervised by technical personnel from the I. ‥ ․․․ 


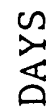

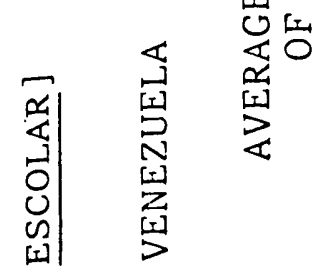

[

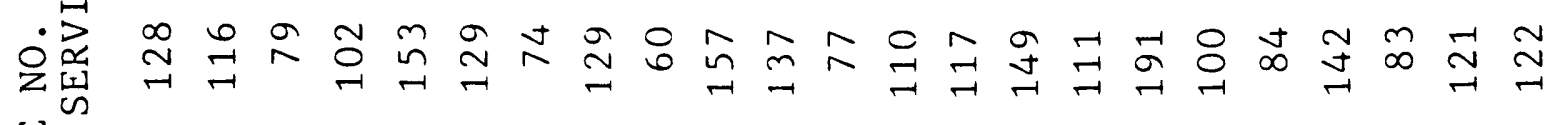
[a]

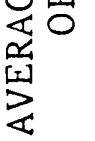

牙永出。

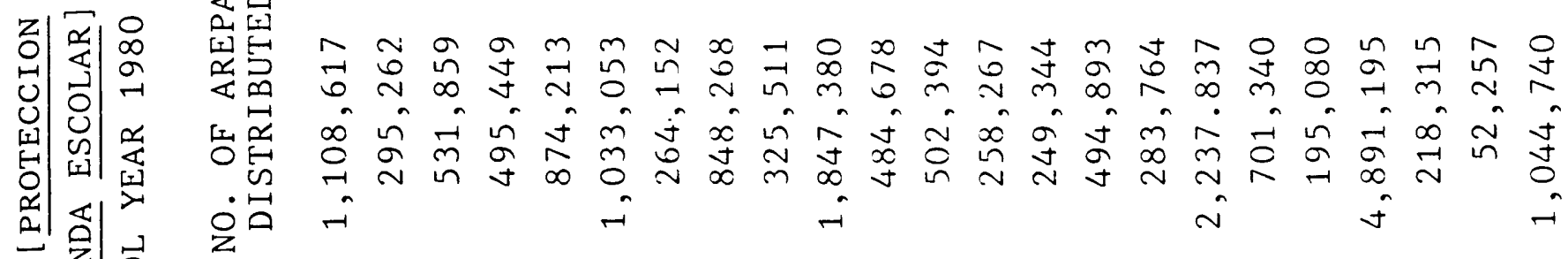
年<smiles>O=[Os]</smiles>

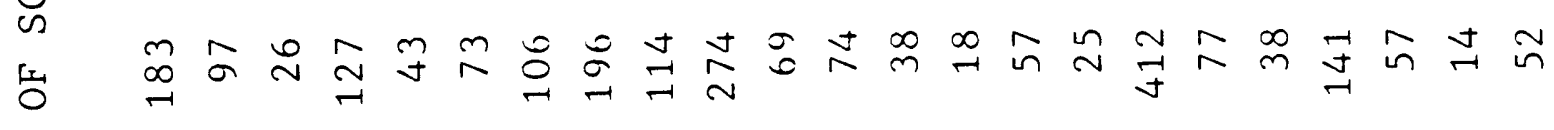
家 ¿̇

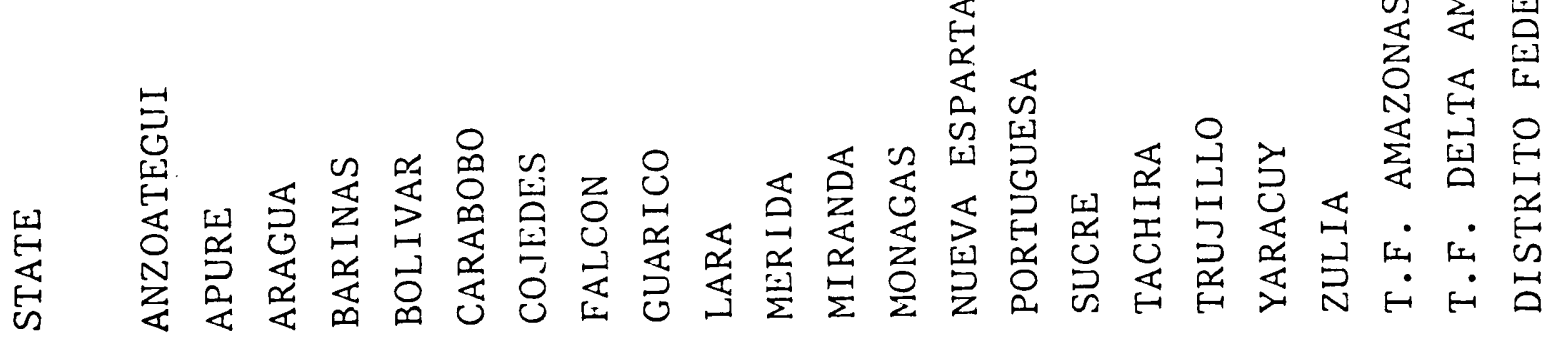




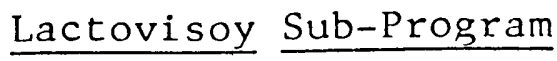

Obiectives:

The main goal of the LACTOVISOY sub-program is to supply pre-school and school children with a product of high nutritional value and protein content which will help in the prevention of iron-deficiency anemias and malnourishment due to lack of iron, proteins and vitamins.

Boundaries:

1) Physical Boundaries
a) Transportation Capacity
b) Distribution Capacity
c) Budget

2) Abstract Boundaries
a) Competence and abilities of management and employees
b) Internal Quality Requirements
c) Governmental Regulations (External) Quality Requirements

\section{Basic Product:}

The basic product Lactovisoy was the result of a series of experiments carried out by the Research Division of the I. N. N.

It has all the characteristics of the Venezuelan "chica," as regards taste, smell and texture, but it made with skim milk, soy meal, rice flour, iron and vitamins.

This product has the advantage of being easily transported over long distances without losing any of its essential properties.

\section{The System:}

This system is primarily involved with the distribution of Lactovisoy to scattered school in rural areas.

Its production is in the hands of private companies with which the $\underline{I} \cdot \underline{N} . \underline{N}$. has made agreements for its manufacturing. Its distribution is divided in two steps: the first one, from the centers of production to the $\underline{I} \cdot \underline{N} . \underline{N}$. storehouses and 
carried out by the company producing the Lactovisoy, and the other, from the storehouses of the $\underline{I} \cdot \underline{N} . \underline{N}$. to the scattered rural schools which is undertaken by the $\underline{I} \cdot \underline{N} \cdot \underline{N}$.

"Glas of Milk" Sub-Program [Vaso de Leche al Escolar] Objectives:

To give a glass of milk to every child attending a public school, containing $200 \mathrm{cc}$ of whole milk, which provides 7 grams of protein and 133 calories. The purpose of this service is to improve the nourishment received by school children and to modify their eating habits.

Boundaries;

1) Physical Boundaries
a) Transportation Capacity
b) Distribution Capacity
c) Budget

2) Abstract Boundaries

a) Management and employees Competence

b) Internal Quality Requirements

c) Government Regulations (External) Quality Requirements

Basic Product:

The basic product is supplied in three forms: pasteurized milk, powedered milk, and milk crackers [galletas de leche].

Requirements to Join the Program.

This service is provided in all public schools in the nation and does not require a special request, as it is instituted by Presidential decree in 1974 which ordered that it should be provided in all public schools in the country.

The System:

Since the product is provided in several forms, the system 
consists of two aspects:

1) Whole milk is delivered directly to the schools by milkcompanies which the $\underline{I} . \underline{N} . \underline{N}$. has contracted.

2) Powered milk and milk crackers are manufactured by private companies and sent to the distribution centers of the I. ‥N. to be later delivered to the schools. 
School Cafeterias Sub-Program [Comedores Escolares]:

The Comedores Escolares are attached to elementary schools in which children of school age ( 7 to 14 years old) receive a noon meal lalmuerzol, which becomes their complimentary nourishment for those who show deficiencies in their nutritional state or have socio-economic problems. To this effect there are 2,475 Comedores Escolares in service at a national level, which served 266,294 school children with 32,643,092 meals in 1980 .

Objectives:

The Comedores Escolares aim to educate and give orientation on nutritional matters, besides providing a balanced "almuerzo" to the students who fill the requirements established in the Internal Regulations Code of the Comedores Escolares.

To adequately protect the children through adequate nutrition in order to reduce the morbidity and mortality rates, and help the students achieve a healthy physical and mental development, and to educate them on nutritional matter to foster adequate eating habits.

Boundaries:

1) Physical Boundaries
a) Tools and Equipment
b) Storage Capacity
c) Production Capacity
d) Transportation Capacity
e) Distribution Capacity
f) Geographical Area
g) Budget

2) Abstract Boundaries

a) Management and Employees Competence and Abilities 

b) Internal Quality Requirements
c) Government Regulations (External) Quality Requirements

The Product:

The product involves a series of well-balanced meals for which a MENU PLAN was carefully designed, and which fulfills the technical standards established by the $\underline{I} \cdot \underline{N}$.. . and is shown on the separate sheet that follows this page.

These menus were elaborated to obtain the following averages for calories and nutrients:

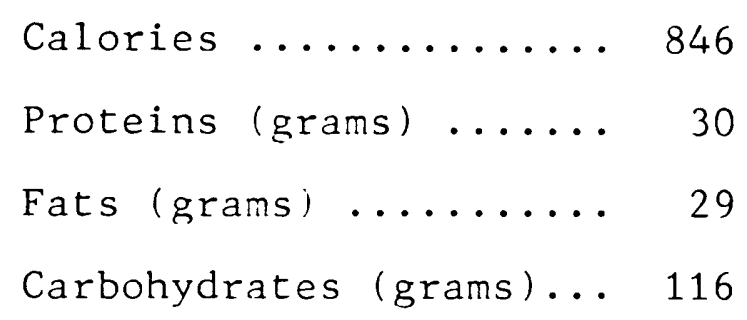

Requirements to Join the Program

The School Principal, together with representatives from the Parents Association and of the Student Body, will make the request for the service to be rendered at their school by the $\underline{I} . \underline{N} . \underline{N}$. The $\underline{I} \cdot \underline{N} \cdot \underline{N}$. will undertake a study of the local needs and the feasability of setting up a program of Comedores Escolares for the school in question.

The System.

The purpose of this system is to process foods for school meals \almuerzos J according to the Menu Plan shown previously and the standards of the Internal Regulations of the Comedores Escolares.

The most important person in this system is the economa [supervisor], who is responsible for the smooth functioning of the Cafeteria in all its operations and is the person in a managerial position that is closest to the personnel of the Comedor. 


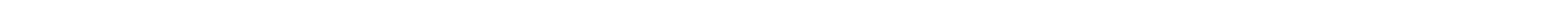


The system, as is presently structured, will be shown as follows :

INPUT.

I. Personnel.

The Ecónoma [Supervisor] is responsible for the coordination and smooth functioning of all the operations of the Comedor, and is the person in an administrative or managerial position that is closest to the workers. Her main responsibilities are:

1) To assign each worker his or her tasks and duties and supervise the strict fulfillment of these, informing the management of any mistake or breach of duty committed.

2) The subordinate personnel will follow the regulations laid down by the Ecónoma so long as these do not interfere with the Regulations of the Program or with the laws in force in the country.

3) While the worker is working, he or she must wear the corresponding uniform, which must follow the model provided by the $\underline{I} \cdot \underline{N} \underline{N}$. No other type of wear will be allowed.

4) The Ecónoma will assign each worker the corresponding work schedule, which the worker must strictly follow.

5) The Ecónoma will enforce the laws as to disciplinary measures for repeated absenteeism from work.

6) She will inspect the workers to make sure whether their uniforms, personal hygiene and other criteria meet the minimum set of conditions that should exist in a food establishment.

7) All the school cafeteria personnel will receive their meals in the Comedor, according to regulations of the Comedores. 
II. Economic Resources.

The amount of funds available to the Cafeteria depends on the number of children in the sub-program, to which effect the Ecónoma [again, Cafeteria Supervisor] will be in charge of obtaining from the $\underline{I} \cdot \underline{N} . \underline{N}$. the monthly subsidies, pay the personnel, and keep the accounting records up to date in accordance with regulations.

III. Menu Plan.

The composition of each daily meal served in the Comedores Escolares will follow the Regional Menu Plan prepared by each individual Unidad de Nutrición [Nutritional Unit], and duly supervised by the Nutritional Division for Public Health of the I. N. ‥

The Ecónoma is to make sure that there is a permanent and adequate supply of all the necessary items for the smooth operation of the Comedor. Only due to extraordinary conditions, such as the total lack of availability of certain products needed for a specific menu is the Ecónoma allowed to use substitutes for those items.

When the Ecónoma finds herself under the need to alter the composition of some of the standard menues, she must make an entry in the daily book of records of the Comedor showing why she had to utilize those substitutes.

The Ecónoma will decide the preparation of the daily meal [almuerzo] based on the Menu Plan devised by the Nutritional Unit, and giving the proper orders to the subordinate personnel as to the tasks for the day and the standards to be followed. 
IV. Recipients of the Service.

The recipients will be:

a) Students of elementary schools funded by the National, State or City Governments, who must show a nutritional deficiency caused by low food intake or by underpriviledged socio-economic conditions.

b) The teacher on duty at the School Cafeteria [Comedor].

c) An invited representative.

d) The Comedor personnel.

At the beginning of the school year, the Economas are to make a census of the student population registered in the school. That survey should include the name, age, weight, height and socioeconomic information on each child. Such data are to be sent by the Ecónoma to the physicjan from the local health organization, who will be in charge of authorizing entrance to the Comedor, giving preference to children whose nutritional deficiency be greater than $18 \%$.

Without previous consultation with the Nutritional Unit Chief, the Ecónoma ahould not register those children who do not have the proper authorization for admission.

The students who are recipients of the Comedor's services will be terminated for any of the following reasons:

a) End of the school year.

b) Gaining back their normal nutritional state.

c) Improvement of the socio-economic conditions of the child's family which justified his entrance into the sub-program.

d) Moving to a nearer residence, in case the excessive distance from the child's home to the school was the original reason for his admittance to the service. 
e) Repeated and unjustified absences, which during a period of two (2) months reach $25 \%$ of the working days of the Comedor.

f) When the child can no longer be considered a student, because he or she is not enrolled in any elementary school.

g) Persistent bad behavior that disrupts the discipline in the Cafeteria, as attested by the Ecónoma and the teacher on duty. V. The Equipment.

The equipment is assigned according to the number of recipients that can be serviced in the Comedores Escolares, which is from 25 to 600 . The equipment is divided in:
a) Heavy Equipment and Furniture
b) Cooking utensils
c) Dishes, pots, pans, etc.
d) Miscellaneous
e) Uniforms

Remark: The Sub-System for Purchases.

A special mention should be made about the sub-system for purchasing, since purchasing is one of the main elements within a system geared to provide food for students on a large scale.

Purchases of food and other supplies are made by each school separately. They are made daily by the Ecónoma in most schools. Purchases are made according to the Menu of the day and in the required quantities needed to prepare that Menu.

The Ecónoma chooses directly the merchants without previous bidding, using her personal iudgement.

The control on the amount of purchases is provided by the funds budgeted for the school, which keeps in relation with the number of recipients it has been assigned to serve. The only requirement established by the Administrative Accounting Unit 
of the $\underline{I} . \underline{N} . \underline{N}$. to justify expenditure of funds delivered is the return of bills whose total amount should equal the amount of money granted to the school for its Comedor. The number of working days is also taken into consideration. The Ecónoma is also receives the foodstuffs and other types of purchases.

Preparation.

The preparation of meals is carried out in a separate manner by each individual school. The complexity of the process is directly related to the equipment that has been assigned.

A great deal of raw foodstuffs is used in the preparation of the meals. These meals are prepared on the same day they are consumed due to the lack of properly-equipped storage spaces.

In the majority of cases, no so-called "production lines" are used in the preparation of meals. The personnel employed for the preparation of meals uses techniques and procedures learned at home, since most do not receive a true training. Oftentimes, the Economa is the only professional in the staff.

Since most menues are not very sophisticated, they do not require a complex preparation either, which is why this subject will not be studied in greater detail.

OUTPUT.

The meals already prepared should fulfill the standards set by the Menu Plan, which requires that the meals ready to eat be served to the student in an environment which is pleasant to school children, be at an adequate temperature, have a good presentation and adhere to all hygiene requirements.

The size of the portions is regulated by $\underline{I} . \underline{N}$. ‥ provisions. 
The techinical supervision of Comedores Escolares will be dnoe by Rural Medical Units, Sanitary District Management Offices, Program Area Management Offices, Nutritional Units and other dependencies of the Instituto Nacional de nutrición.

The Comedores Escolares Program depends on the Nutritional Division of Public Health for its standards, and on the respective Nutritional Unit for administrative and technical matters.

The Economa is to write down in the Daily Book of Records of the Cafeteria the menu served, including the corresponding number for the menu in the Regional Menu Plan, and will sign daily the sheet corresponding to the date, together with the kitchen supervisor and the teacher on duty.

The Cafeteria Supervisor [Ecónoma] is responsible for the safety of all furniture and utensils, of their care and upkeep.

She is responsible for making inventories of all existing material and equipment in the Comedor, and for sending an annual physical inventory to the Nutritional Unit in the month of November.

Without a written authorization signed by the Nutritional Unit Chief, the Comedor personnel is not allowed to provide meals to any person that is not considered in the program outline.

The $\underline{I}$. N. … will provide technical personnel, who will be in charge of periodically supervising the Comedores and of making pertinent suggestions to improve service, which are to be put into practive.

In each Cafeteria [Comedor] there will be a Book for Supervisors, with numbered and stamped pages, in which the supervisors will write the results of their investigations. The Book will be 
ings with the doctor and the nurse in charge to discuss the health of their children. The teacher's attendance is very important. Efforts will be made at such meetings to underscore the importance of personal hygiene.

The school principal is to receive all information regarding the list of attendance at the Comedor and be aware of all cases whose rate of absences goes over the allowed limits.

The Economa should make the daily and monthly reports to be sent to the $\underline{I} \cdot \underline{N} . \underline{N}$. on handling of merchandise, number of meals served, distribution of costs, student attendance to the Comedor, foods in stock and the summaries on average number of working days, income and expenses, break-down of income and expenses categories, patterns of student attendance and results of inspectors visits. 
Field Research.

To verify la information gathered in the government offices that have the duty to implement and develop the School Child Nutritional Care Program L Protección al Escolar| and its respective sub-programs, a series of visits were carried out to different Comedores Escolares chosen at random and located in the Capital Region, states of Aragua, Zulia and Carabobo, as it is in these areas that the greatest concentrations of elementary school student population are found.

The information obtained in the fiel $d$ research cannot be presented in a scientific manner, as the request for permission to make official visits to the schools was denied by the division in charge of granting such permits in the $\underline{I} \cdot \underline{N} . \underline{N}$.

Due to the aforementioned fact, the visits that were carried out were of a strictly informal character, reason why the information gathered from the personnel in charge of the School Cafeterias [Comedores] was obtained through personal conversations, since the persons being interviewed were not authorized to give any information and much less statistical data about the operation of the program in question.

Though the report that follows lacks strictly scientific support, it nevertheless reflects a reality that can be easily checked. I wish at the same time to attest to the fact that this information was gathered with no motivation on my part other than to present a research project on the present operational reality of the Programa de Protección al Escolar [School Child Care Program]. The obtained data is detailed as follows:

Merienda Escolar [School Snack] 
Regarding the School Snack Sub-Program the following information was gathered in 21 public elementary schools:

The implementation of this program was begun in 1976 in the states of Zulia and Yaracuy and was later expanded at a national level. It has, however, experienced a drastic reduction in the scope of its intended population of recipients to the point that in the present time is practically non-existent.

In the elementary schools where the program is still in service, supervision problems by the $\underline{I} \cdot \underline{N} \cdot \underline{N}$. have caused a lessening of the quality of operations with the result that the service rendered does not fulfill the standards originally established.

Where the program is still in operation the students are receiving a qualitatively sub-standard product which is freauently unappetizing and whose preparation does not fulfill the minimum health standards.

The continuity of service is often interrupted by circumstances such as illness on the part of the ladies who provide the service and other problems of a family or personal nature.

Soy-Enriched Milk Product (Lactovisoy)

This program was begun in 1980 and is still at an experimental stage. It is not being offered on a daily basis and is provided to a very small population.

None of the schools visited offered this program.

"Glass of Milk" Sub-Program [Vaso de Leche ]

This service was started in the year 1974 in the nation's public school with great ambitions. As reflected in the interviews with the program personnel, this program has suffered a significant reduction in its scope and experienced irregularities in 
providing the service.

Due to the lack of proper refrigeration equipment to preserve the milk on the occasions when there is a surplus, losses have resulted, with the milk having to be immediately distribuited in the community.

The product is not delivered in a manner that assures that the quantities are those estipulated by the I. ‥ ‥

The consumption of the product by the school children is not supervised, so there cannot be any assurance that the student is consuming his assigned portion of milk.

Comedores Escolares [School Cafeteria (Meal) Sub-Program]

In a group of 23 Comedores visited the following information was gathered on this sub-program:

Facilities:

The buildings that were visited had not been originally intended to serve as dining rooms and their conditions did not fulfill the minimum requirements for a food establishment.

It is worthy of notice that in some cases the Comedor is outside of the school building, which forces students to walk over considerable distances. This brings about irregular attendance on the part of the children, depending on the weather, and a lack of enforcement of attendance on the part of those in charge.

Service areas are not kept up to provide adequate service, as the furniture is insufficient and is not maintained properly. In some cases there are no restroom facilities with adequate installations such as sinks, toilets, etc.

The general environment of the Comedores is not pleasant for 
the children.

Production Areas.

The production areas have not been designed and distribu ted properly in space with the purpose they are to be used for in mind.

Storage areas are practically non-existent and most do not even have the minimum refrigeration equipment needed.

There are no areas to receive the merchandise.

Kitchen equipment is often incomplete and in some other cases is underutilized.

Menus.

In the process of double-checking the information received from the $\underline{I} . \underline{N} . \underline{N}$. offices regadring the menus it was found that: The menus supplied as of 1979 by the $\underline{I} . \underline{N}$. … were not known by the Economas interviewed.

The last menus sent by the $\underline{I} . \underline{N} . \underline{N}$. are from the year 1970, which are not being followed either.

The menus that are presently and actually offered are made up by the Económas according to their personal opinion and funds available.

In the preparation of the menu, the nutritional value of the different foods are not taken into account.

Personnel.

The personnel assigned to the Comedores, with the exception of the Economa, lack the necessary training to insure an efficient utilization of the available resources.

The $\underline{I} \cdot \underline{N} . \underline{N}$. requirements for Ecónomas are two:

a) To have passed the third year of secandary education.

b) To have passed a training course of 3 months duration. 
The Economas are not given opportunities to further their professional education.

Service Recipients.

Selection Process:

In the Comedores visited, the Economas are the only ones in charge of making the yearly report and selecting the children who will receive the service. In some cases the teacher gives advise on this matter, and only very rarely are the Economas advised professionally by the medical personnel on the process of selection.

The most important factor in the selection process is the number of recipients that the $\underline{I} . \underline{N} . \underline{N}$. sets out for each institution, without taken in consideration the real needs of the children. If the number of children with nutritional deficiencies surpasses that number allotted by the $\underline{I} . \underline{N} . \underline{N}$. , then those children will not be able to become recipients of the program, since anyway the per capita daily allowance is very small, $\$ 0.50$ per child, and does not allow the Economas to extend the service to other children.

Due to the lack of medical personnel there is no follow-up of the nutritional development of the child, which makes the program's efficacy impossible to evaluate.

Supervision and Controls.

The supervisional aspect that receives the most emphasis from the I. …… is the administration and accountibility of the program funds, while the operational and technical supervisions are practically not carried out.

In some cases the school principals offer their collaboration 
to help the $\underline{I} . \underline{N} . \underline{N}$. in supervising the Comedores.

As far as internal controls are concerned, the Ecónoma is the only one in charge of their execution.

Feedback.

The $\underline{I} \cdot \underline{N} \cdot \underline{N}$. receives hardly any information from the Comedores Escolares, and whatever is received is reduced to:

Monthly reports on production, menu offered, cost involved, total number of people serviced.

Attendance records.

Expenditures Break-down Reports.

There are no periodical meetings between representatives of the parents, students, school principals, Ecónomas and representatives of the $\underline{I} \cdot \underline{N} . \underline{N}$.

Field Research Conclusions.

As can be evidenced, the results of the field research conducted indicate that the goals originally set-out are not being achieved and, which is more serious, there is a marked tendency towards decreasing service in the last few years.

The children's nutritional needs are not the guidelines for the quality standards and scope of the Programa de Protección al Escolar [School Child (Nutritional) Care Program]. These are only based on the budget that the Government assigns for those purposes.

It can be said that the only program that has remained in full service is that of Comedores Escolares, though with a lot of deficiencies.

Controls and supervision by the $\underline{I} . \underline{N} . \underline{N}$. have been insuffi- 
cient, since they have not consistently enforced regulations that would allow the fulfillment of requirements and procedures.

A great waste of efforts and funds can be observed, to the effect that none of the programs are fulfilling their intended goals.

Facilities are not adequate to render the service offered, as they dorot pass the minimum sanitary requirements established by the $\underline{I} \cdot \underline{N} \cdot \underline{N}$.

Kitchen equipment is some cases is insufficient and in others is not used to its full.

Storage areas are inadequate to keep foodstuffs. This does not enable the Comedor to save on large volume purchases, as it does not prevent either the spoiling of surplus food.

Menus are not prepared according to the nutritional value of the entries.

The necessary feedback for the correction and improvement of the programs is not being gathered nor processed, with the result that the extent of the flaws of the programs is not known.

The $\underline{I} \cdot \underline{N} \cdot \underline{N}$. per capita allotment is not in tune with the bying power of Venezuelan currency at this point in time. The assigned per capita of allotment of $\$ 0.50$ dates back to 1979 , and has not been updated to account for the inflation rate in Venezuela, which amounts annually to $30 \%$. What this allotment does is to barely and medriocrely satisfy the organism's prime need to ingest food, without taking into account other basic factors that are related to a good physical and intellectual development of the child. 
THE DATA AND

THE TREATMENT OF THE DATA

The Data.

The data of this research is divided into two types: primary data and secondary data. The nature of these two types will be given below.

The Primary data. The primary data consists of the material gathered from the interviews with the following types of personnel involved in the program under study:

I. N. N. administrative personnel

Elementary school administrative personnel

Comedores Escolares supervisory personnel

The Secondary Data. The secondary data consists of several publications and samples of public documents and legislation. The publications by the $\underline{I} \cdot \underline{N} \cdot \underline{N}$. are:

Memoria y Cuenta, 1980-1981

Internal Regulations for the Comedores Escolares

Publication for the XXX Aniversary

Activities Reprot for the year 1980

Outline of Menus for School Meals

Collection of research studies by the $\underline{I}$. - . N.et al.

Publications by the $\underline{M}$. E.

Statistics Report on Elementary Schools and Elementary Schools Student Population for the year 1980 .

Publications by the $\underline{M} \cdot \underline{S} \cdot \underline{A} \cdot \underline{S} .:$

Sanitary standards for the processing of foods in mass production facilities. 
The Location of the Data

Compilation of research studies carried out by the I.N.N. together with other organizations at a national level.

Memoria y Cuenta 1980-1981, by the $\underline{\text { I. }}$ ‥ ․․․

Activities Report for the year 1980 , by the $\underline{I} . \underline{N} . \underline{N}$.

Answers given in the interviews

National Constitution

Child Protection Law [Ley Tutelar del Menor]

The Treatment of the Data

The results of the compilation of $\underline{I} \cdot \underline{N} . \underline{N}$. research studies, which were presented under the title Nutritional Problem Overview, show that a high percentage of the children population under 15 suffer from a high level of malnutrition. This is especially true in the lwoer socio-economic groups, in which family units earning less than the minimum subsistence salary can be found. Since thiese families do not have the resources to provide their members the minimum necessary food intake to insure a healthy physical and intellectual development, the government is the only one that can be called upon to provide for them, as established in the Ley Tutelar del Menor, which was derived from the National Constitution of Venezuela.

The Programa de Protección al Escolar [School Child Care Program], composed of 4 sub-programs, is satisfying only a small portion of the national nutritional needs. As shown by the statistics on the population serviced by each sub-program, the sub-programs have had to reduce their scope although the population keeps increasing in numbers.

The sub-programs are not reaching their original qualitative goals, since no scientific guidelines are followed which will 
guarantee the nutritional content of meals to be adequate, which will grow worse unless the budgets assigned to each sub-program are revised and increased.

Subproblem Two. The subproblem number two is to identify and analyze the structures of the present nutritional programs servicing the population of elementary school children and to compare them with a single program that will centralize all efforts in an effective program that will really satisfy the nutritional needs of that population.

The Data Needed

The data needed for the solving of subproblem two is:

a) Description of the system used by each sub-program

b) Proposed system

The Location of the Data Memoria y Cuenta 1980-1981, by the $\underline{I} \cdot \underline{N} \cdot \underline{N}$. Internal Regulations of the Comedores Escolares I.N. N. Activities Report for the year 1980 Outline of Menus for Elementary School Meals New System Design

Field Research

The Treatment of the Data

From the description of the systems used by each one of the sub-programs, we found that in spite of having the same objective, they function individually and independently and that is why totally different organizational structures have had to be created 
for the execution and supervision of each one, bringing about as a result the wasting of efforts and economic resources assigned, which increases the likelihood of failure in the effort the reach the goals that had been originally set.

This combination of circumstances has weakened the evolution of the programs and has caused a diminution in the scope of those programs.

One single system, as the one proposed, would concentrate all efforts and the economic resources assigned to the $\underline{I} \cdot \underline{N} . \underline{N}$. by the National Government. Besides, a more rational and efficient utilization of those resources could be achieved, which would translate as a whole into an improved rendition of service which would truly fill the nutritional needs with a better-quality product, which follow the nutritional standards necessary to insure a balanced meal.

Subproblem three. The subproblem three is to identify and analyze the governmental and legal framework that presently regulates the operations of nutritional programs and to point out whre the governmental and legal structures are preventing a better development of these programs due to the specific governmental and legal delimitations that have been imposed.

The Data Needed

Structure of the Venezuelan Government in relation to

Nutritional Programs (Outline)

Organizational Structure of the $\underline{I} \cdot \underline{N} \cdot \underline{N}$. (Outline)

Historical Review

Venezuelan Constitution

$\underline{\text { Ley }}$ Tutelar del Menor [Child Protection Law] 


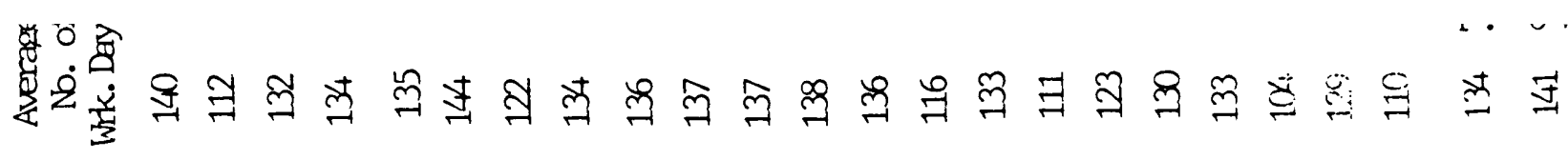

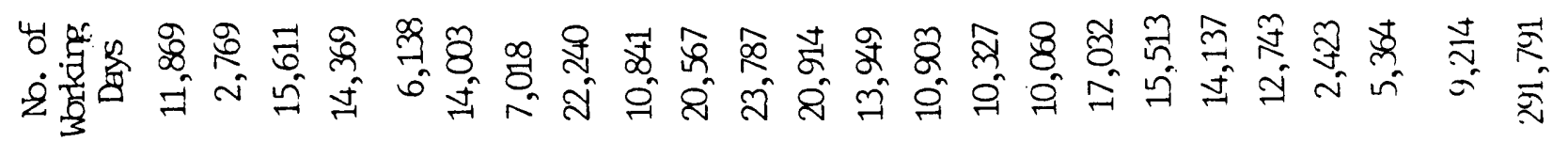

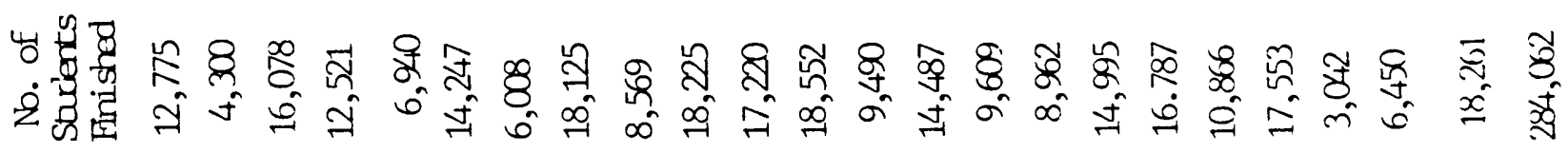

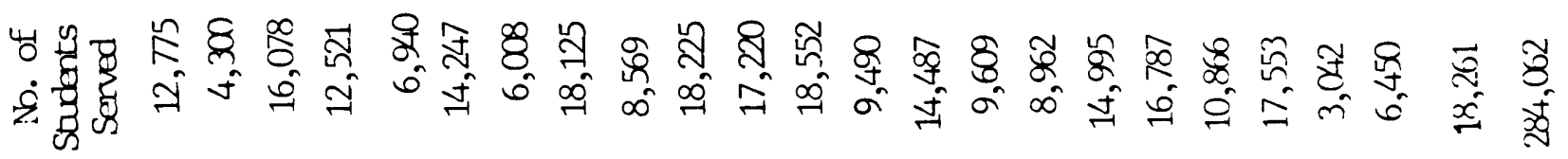

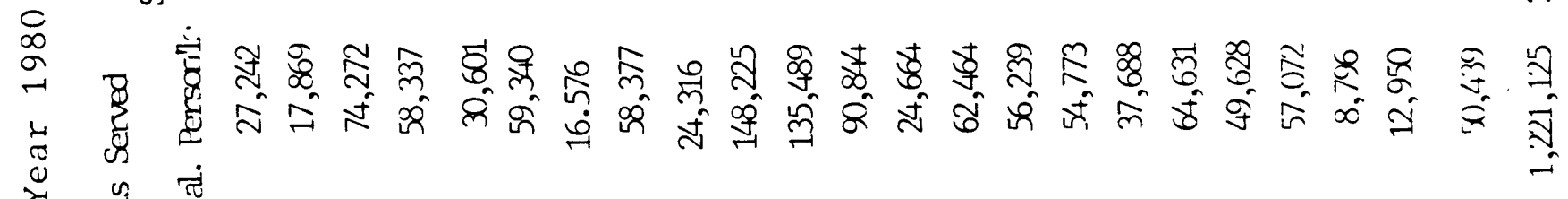

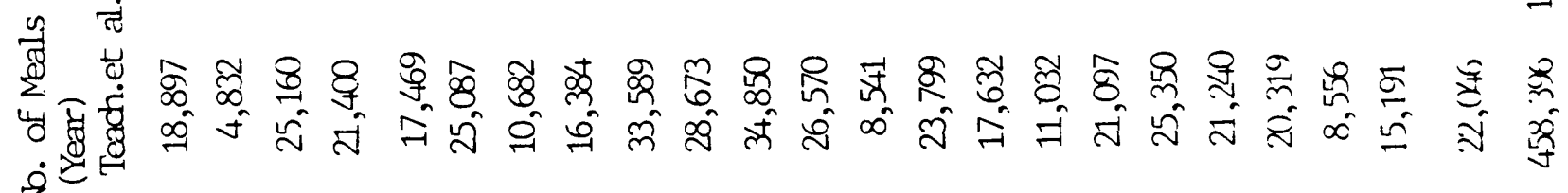

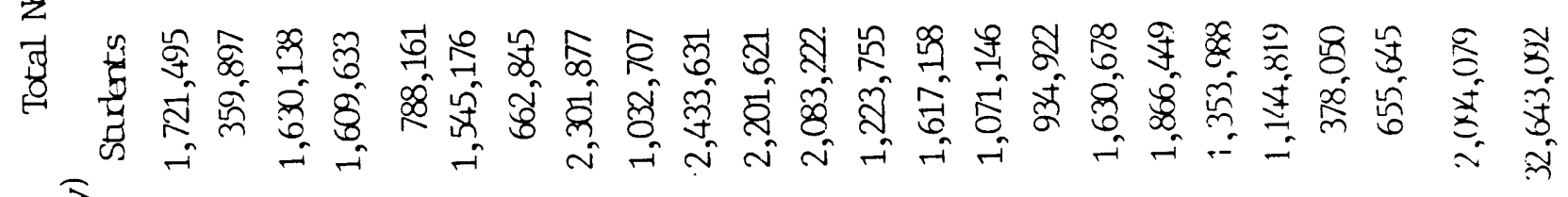

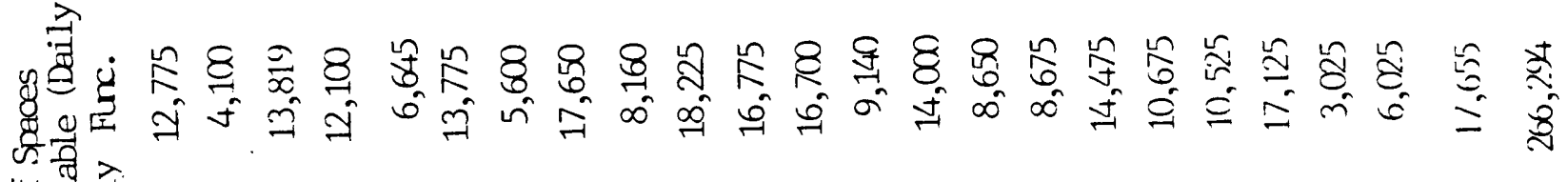

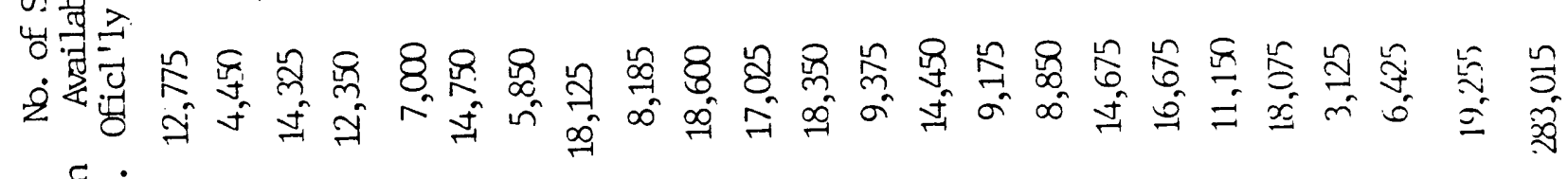

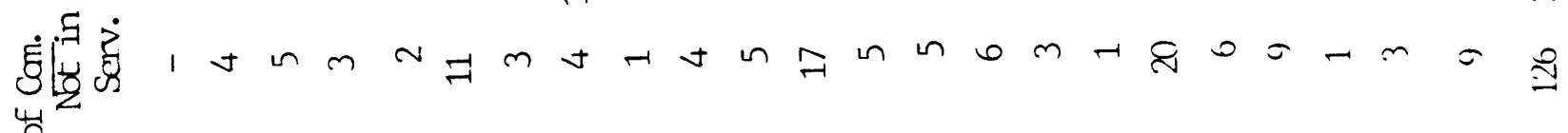

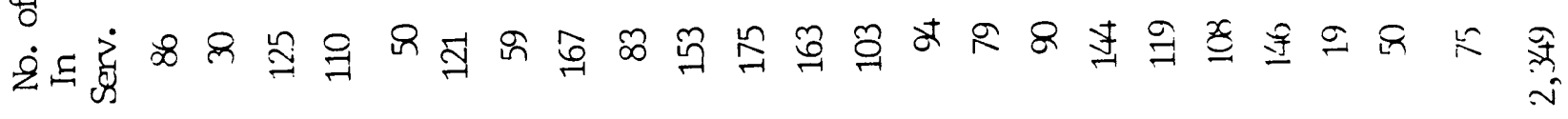

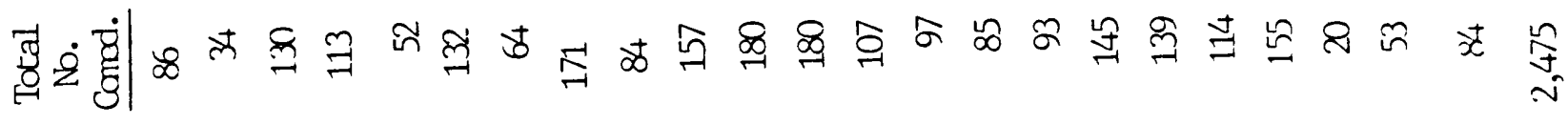

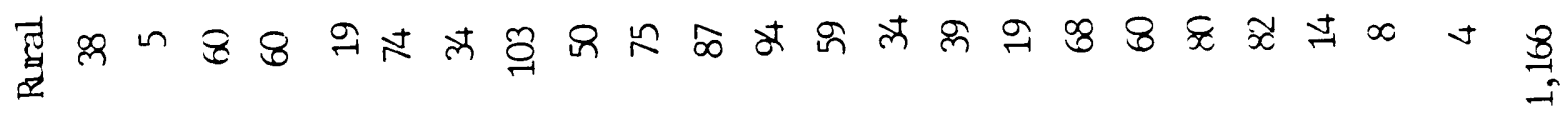

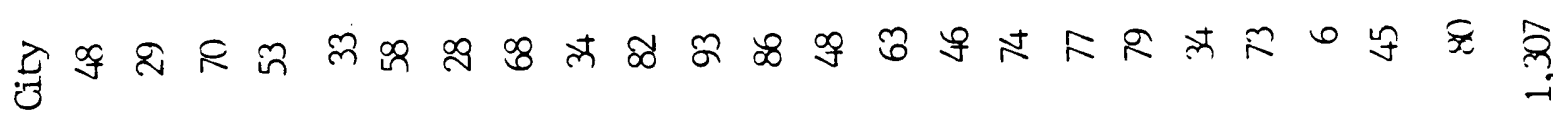

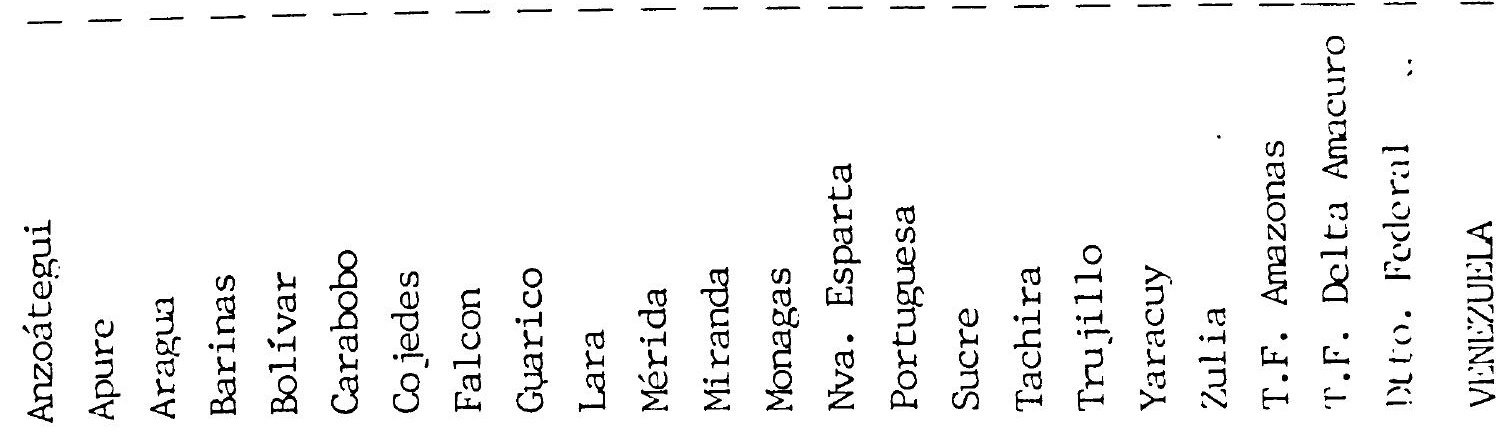


The Treatment of the Data

The outline presented about the organizational structure of the $\underline{I} \cdot \underline{N} . \underline{N}$. clearly shows how the different offices and administrative departments are subdivided and inter-related.

The Venezuelan Constitution is the source of several laws having as a goal the protection and care of children. One of them is the Ley Tutelar del Menor [Child Protection Law], whose ordinales I and II clearly establish the obligation of the goverment, in the abscence of the parties legally responsible for the care of the children, to provide the conditions for the cild's healthy physical and mental development.

This obligation that the government has has brought about a series of efforts with the intention of creating an organization that would be capable of handling all problems related to nutrition, and, as presented in the Historical Overview, the $\underline{I} \cdot \underline{N} \cdot \underline{N}$. came into being as an autonomous institute, with total responsibility for all nutritional problems.

This institute is related only to the $\underline{M} . \underline{S} . \underline{A} . \underline{S}$. , thus disregarding the importance of a direct relationship with the Ministries of Education and that of Agriculture and Cattle [Agricultura y Cria], so all elementary schools receiving the $\underline{M} . \underline{S} . \underline{A} . \underline{S} . ' s$ Protección al Escolar Program [School Child Protection Program] are under the sole responsibility of the Ministry. The greatest provider of foodstuffs at a national level is under the administrative powers of the Ministry of Agriculture, which is the Corporacion de Mercadeo Agricola [Corporation of Agricultural Products], which offers the lowest prices in the market and that to this day has 
not played a major role as a provider of the foodstuffs needed for the execution of the nutritional programs.

As to what concerns supervision, this lack of inter-relatedness created by the legal and organizational structure results in the fact that school teachers and principals have no obligations to fulfill under the programs. This personnel could be the foundation for an efficient system of supervision as they know the problems as they arise on a day-to-day basis.

Location of the Data

Memoria y Cuenta 1980-1981

I.N.N.'s XXX Aniversary Publication

Ley Tutelar del Menor Article No. 1, Ordinales I and II.

Manual de Derecho Administrativo [Administrative Law Manual]:

Definition of Autonomous Institutes

Venezuelan Constitution: Articles on Children's Rights.

Subproblem Four. The subproblem four is to analyze how the different human and economic resources are being assigned to nutritional programs at the elementary school level and to point out how this same resources can be rationally and efficiently used and how it is possible to find new sources of funds which make possible the expansion of these programs to include a larger sector of the student population.

The Data Needed

Economic Overview

Analysis of the present system used for the School Meals 
The Location of the Data

Memoria y Cuenta, by the I. ‥ …, 1980-1981

Activities Report for the year 1980

New System Design

Ley Tutelar del Menor [Child Protection Law]

Field Research

The Treatment of the Data

As can be observed in the Economic Overview, the budget for the Programa de Protección al Escolar [School Child Care Program] has been decreased, at the same time as its present distribution among the different subprograms disperses even more the economic resources among the programs that are reducing their services for not reaching their goals and among others that still are on an experimental basis without there being any certainty about their efficacy.

To the extent that the efforts be integrated in one single program that will make possible the maximum, rational use of the available human and economic resources, will it be possible to render a service that is in tune with the nutritional needs of school children, which can only be achieved through the elimination of all sub-programs other than the Comedores Escolares, which would integrate them into only one program that should be re-designed in accordance with the guidelines presented in the new proposed system based on satellite production units.

The idea is also put forth that new sources of funds be obtained, that would increase the budget and would enable the programs to expand the number of recipients of their services. 
These funds would come from that section of the student population that, through a selective process that would evaluate their socio-economic level, was shown to be able to pay for the service in full or at a reduced price. 


\section{THE "SATELlite" KitCHEN}

The traditional method of serving their meals to school children is the "on-site" arrangement, with a fully equipped kitchen in each school, preparation and cooking of foods in great quantity in that kitchen, a specially set-aside dining room or "cafeteria" with hot tables and other serving equipments and eating tables, permanent hardware (trays, knives, forks, etc) and dishwashing, equipment. This type of traditional installation has to be built inside the school or added to it, making for more capital plant expenditures. Each school has to have separate labor force.

New methods are challenging the traditional one. One alternative now being used in many schools is "satelliting." Food is prepared in a central plant and usually pre-portioned, often in disposable plastic containers that eliminate dishwashing. It is then transported, either hot or cold, to many schools in the area. This type of central processinng of food eliminates the cost of having a complete kitchen in each school. Simple and relatively inexpensive refrigerators and convection ovens to re-heat the delivered food can be stored in an amazingly small space- usually less than 100 square feet. Empty rooms, classrooms and even hallways can be used as dining areas - a special consideration in outdated schools that cannot simply a facility to serve meals built in or even added to the building. Personnel costs are obviously less, becasue fewer persons are needed in each school, and the efficiency of central preparation (in large quantities cuts the cost per school. 
separately and can be given to the student from a refrigerator or cold-room. The students eat their meals in trays, which they return for washing and sanitizing at the central kitchen.

A variant approach would be to send only the hot and cold food carts from the central kitchen to the schools, which would keep a supply of trays and tableware. This requires garbage disposals and of course washing machines in those schools. Still another variant: only some types of food are prepared at the central kitchen, usually the hot foods, and the rest of the meal can be prepared at a satellite kitchen.

In the pre-portioned service, the meals are prepared and packaged individually in the central kitchens. They may then be delivered hot, chilled or frozen. Several types of methods of delivery are as follows:

* "Twin-pack"-A combination of hot and cold pre-portioned foods. The "hot pack" contains an entree and one vegetable which are usually wrapped with aluminum foil or plastic. The hot pack is reheated at the receiving school, so it can be delivered either hot or cold. The cold pack contains the rest of the vegetable foods-fruit, bread, butter, and disposable eating utensils. The pre-portioned meals are refrigerated at the receiving school until meal-time, at which hour the simple and relatively cheap convection ovens can be used for re-heating.

* Polystyrofoam compartment tray - The foods are pre-portioned into disposable, compartmented polystyrofoam trays, sealed with a lid and placed in insulated or electrically heated 
containers for transportation purposes. The receiving school can then serve the hot meals straight from these containers.

* Tray pack - Generally pre-chilled components are pre-portioned and sealed into the tray by wrapping it with plastic foil, and kept refrigerated at the receiving school until served.

* Box or bag meal - This type contains cold foods, with each item individually wrapped in moisture-proof paper or a sealed plastic container, and delivered as a unit with disposible eating utensils.

\section{A Model Satellite System.}

The latest hardware and handling techiniques can eliminate costs in more conventional systems. The center is designed for rapid processing of foods and for most efficent utilization of space and labor. Some of its features are:

* Litensils, tables, are counters for easy cleaning and long lasting use, with water and steam hoses conveniently located. * Movable tables, with wheels, of the same hieght as the counters, which can add length and width to these as need arises. * Timers and automatic equipment should be used when needed.

School Breakfast Program.

A School Breakfast Program must be designed in each school to provide a nutritional breakfast for children. These breakfast in turn must meet nutritional standards, which means they must provide a combination of foods: fruit or juice, milk, bread or cereal. A high protein food must be served as often as possible. 
Special Milk Program.

Ob jective.

The purpose of the Special Milk Program is to encourage children to drink more milk by reimbursing the schools for part of the cost of the milk. Schools can then provide milk at a reduced price through the Special Milk Program if they develop a plan for increasing milk consumption by the children, which would make them eligible for the funds. Schools with a large population of poor children may be re-imbursed for the full cost of the milk so it can be given free to those children. This program could be especially important in schools in which there are no established Comedores Escolares.

\section{New Special Meal Service Program.}

This New Special Meal Program would provide meals to school children in public institutions. The institutions used must be in low-income areas or areas with a large population of working mothers, whose working hours prevent them from making sure their children receive a nutritional meal when they are not home.

Eligibility of Recipients of the New Special Meal Service Program.

The Government, through its organization Cordiplan, set the poverty income level for a family of three at $\$ 465.00$ a month. This minimum income could be used as a standard for evaluating eligibility for all types of poverty programs and, in respect to the program that is the subject of this study, for school meal programs. 
Eligibility Requirements for Schools.

The Government is to require that all schools comply with the following fundamental operatonal regulations to enter the new school meal program:

* Each school must establish its procedures for free and reduced-price meals for the children and have them approved by the $\underline{I} \cdot \underline{N} \cdot \underline{N}$.

* All children from families with an income below the minimum poverty standard must receive free meals. With the approval of the $\underline{I} \cdot \underline{N} . \underline{N}$. the school may raise its minimum poverty limit by $25 \%$ as a guideline for free meals, and by another $50 \%$ for reduced-price meals.

* The school must inform the public of its policies.

* Administrators of the program must accept the families's applications at face value. If they suspect someone is falsifying information to obtain free or reduced-price meals, they must accept their application for the time being until a confidential interview can be arranged to try to solve the situation tactfully and fairly. The children are not under any circumstance be drawn into this problems.

* Schools must not discriminate against children who are receiving this type of aid and must devise the programs as to protect their anonimity.

* Each school must abide by the nutritional requirements established by the $\underline{I} \cdot \underline{N} \cdot \underline{N}$.

* The food operation service of the schools must be nonprofit. * Schools are responsible for keeping necessary records. 
The $\underline{I} \cdot \underline{N} . \underline{N}$. should provide these additional guidelines for the schools:

1. The school must make public its complete set of criteria to determine a family's eligibility, which includes the income scale used by the school.

2. The school eligibility standards must include a minimum of three factors to evaluate family needs: family income, family size, and number of children attending school or day care centers. The number of children does not have to be used if only free meals are provided, but it must be considered if reduced-price meals are to be given.

3. If a school automatically determines a child qualifies for free or reduced-price assistance, parents need not fill out applications for the program.

4. If all children in a school meet automatically the eligibility standards, all parents should be notified that no applications are needed.

5. A school may serve free meals to all children eligible for free or reduced-price meals. In this case, reduced-price meals are eliminated.

6. If the parent will not or cannot apply for free meals, the school may approve them for children on the advise of the teacher, nurse or other school official.

7. The application forms for parents may not include a statement authorizing future checking into his reported income. They cannot require the applicant to inform the school if his income changes nor where he or other family members are employed. 
8. Those in charge of the school meals program may develop their own collection procedure for as long as they protect the anonimity of the children receiving assistance. The system established may not simply allow this children to pass through the 1 ine without paying, if cash payments are used in the mealroom, as this would identify them as recipients.

9. The $\underline{I} \cdot \underline{N} . \underline{N}$. may 1 ist the different collection methods employed by the schools, but may not list which schools are used which methods.

10. If a school employs and pays student helpers, children receiving assitance should not work except if their parents so request. Parents should know that their children will help even if they do not work.

Application for Free or Reduced-Price Meals.

This application should only ask for the information needed to determine the child's level of need for eligibility, and it should not be complicated or ask questions that prove embarrassing to the parent that has to fill it out.

A family member may be defined as "someone living in your house for whom you pay all expenses." Similarly, "family income" requirements may be fulfilled by asking for a break-down of salary, commisions, pensions and other sources of income.

How To Make Collections.

When there are students who pay full or reduced price, the school msut set up a collection system that will protect the anonimity of those receiving assistance. The $\underline{I} \cdot \underline{N} \cdot \underline{N}$. should therefore recommend or enforce these or similar methods: 


\section{For large schools:}

1. Students go to the school office, Comedor office, etc. Those who pay in full or reduced rate pay in money for tickets or tokens, are those who receive free meals get theirs free. These tickets and tokens can be issued on a daily or weekly basis, and since weekly tickets are easier to keep track of for accounting purposes, even discounts should be given to encourage their use. Tickets or tokens for those receiving assistance must be identical to the others except for a secret code number for accounting purposes.

2. A teacher may give each child an envelope for daily or weekly payments, which the students then return with their full, partial or zero payment, according to their eligibility level. The teacher then issues the tickets or tokens.

For Smaller Schools.

1. All the students pay cah, with needy students being given the money for their meals. Program supervisors must insure that that money is used for its intented purpose, and that it is given out in such a way that the student cannot be identified.

2. All students pay cash or buy their meals "on credit." Those paying either full or reduced-price are charged monthly, while those receiving free meals are not charged. To identify students, an I.D. card may be shown to the cashier. The I. ‥ … should warn the schools that a sufficient number of paying students use the "credit" system, as otherwise the only ones using the cards will be the free meal students, who would thus be identifiable. 
THE TEST OF THE HYPOTHESES

Hypothesis One.

This hypothesis was proved as it has been shown that the nutritional needs of school children are not taken into account when school menus are designed in respect to the caloric and nutritional content of the foods served to the children. Likewise, there is a lack of feedback of information on the preparation of meals and the quality of the final product and their adherence of the standards established by the $\underline{I} \cdot \underline{N} . \underline{N}$. There is not either a system of follow-ups on the development of children who received these programs, which would allow us to revise and re-define the goals concerning the fulfillment of the nutritional needs of children.

Hypothesis Two.

Hypothesis Number Two has been proven as it has been shown that the number of children being serviced by these programs is determined by the $\underline{I} \cdot \underline{N} . \underline{N}$. , which only allows to tend to the needs of a small segment of the school children population. Even this budget itself has been cut which consequently will mean an even lesser capacity to service an indeed growing student population.

Hypothesis Three.

This hypothesis has been proven as it has been shown that in the creation of the $\underline{I} \cdot \underline{N} \cdot \underline{N}$. no healthy interdependency was planned that would allow a coordination of efforts and a flow of communication with other institutes and organizations that should 
be involved together in their endeavors, thus facilitating the pursuit of the common nutritional goals and serving as a source of support for the fulfillment of its responsibilities as the organization in charge of identifying and finding solutions for the nutritional problems of the Venezuelan population and especially those of the children.

Hypothesis Four.

This hypothesis has been proven as it has been shown that the economic resources assigned to the $\underline{I} . \underline{N}$. ‥ have been dispersed among different sub-programs that have not been effective, and even one of which is still on an experimental basis and with little likelihood of being implemented with good results. Besides, the diversification of the human efforts that have gone into each program does not allow for the establishment of efficient systems of supervision and feedback that will insure the maintenance and revision of the systems set-up for each sub-program, due to the lack of coordination among them, which brings as a consequence that none of the sub-programs can achieve the objectives that were originally assigned to it. 


\section{RECOMMENDATIONS}

Since the nutritional problems of the elementary school student population is not easy to solve, nor will it be solved on a short-term basis, my recommendation consists in uniting the several efforts and resources now dispersed among the different sub-programs for the nutritional care of school children in one single effort such as the one proposed under the title "New System Design," which would implement the Comedores Escolares [School Cafeterias] program by using the concept of satellite kitchens. 


\section{B I BLIOGRAPHY}

Bard, Bernard, The School Lunchroom: Time of Trial, New York, John Willey \& Sons, Inc., 1968.

Bryan, Mary Degarmo, The School Cafeteria, New York, AppletonCentury-Crofts, 1939.

Constitución Nacional de la República de Venezuela, Caracas, Imprenta Nacional.

Cronan, Marion, The School Lunch, Peoria, I1l., Charles Bennett Co., Inc., 1962 .

Heckler, George and Ruth, School Food Centers, New York, John Ronald Press Company, 1960.

I. N. . . . , Dirección de Información y Relaciones Públicas, XXX Aniversario del $\underline{I} \cdot \underline{N} . \underline{N} .$, Caracas, Génesis, 1979.

- - División de Alimentación Institucional, Normalización de Equipo para Comedores Escolares, Caracas, 1970.

_ - - Divisisión de Nutrición en Salud Pública, Reglamento

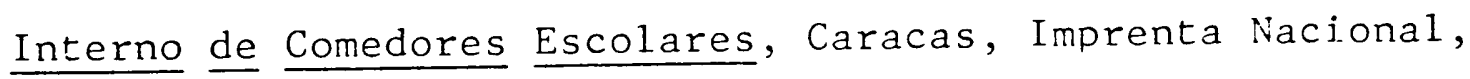
1978 .

- - , Encuestas Realizadas entre $1949=1978$ sobre los Problemas Nutricionales.

- _ , "Informe de Actividades, 1980," Caracas, Imprenta Nacional, 1981 .

_ - , "Memoria y Cuenta, 1980," Caracas, Imprenta Nacional, 1981 .

Kotschevar, Lendal H. and Margaret E. Terrel, Food Service Planning, New York, John Wiley \& Sons, Inç., 1961. 
Leedy, Paul D., Practical Research, New York, Macmillan Publishing Co., 1980 .

Ley Tutelar del Menor, Ley de Menores, Caracas, Imprenta Nacional.

Martínez Eloy, Lares, Manual de Derecho Administrativo, 3a. Edición, Caracas, Avila Editores, 1975.

M.E., Encuestas sobre Instituciones Oficiales de Educación y Población Escolar, Caracas, 1970.

$\underline{M} \cdot \underline{S} \cdot \underline{A} \cdot \underline{S} \cdot, \underline{I} \cdot \underline{N} \cdot \underline{N} .$, División de Investigaciones, "Tabla de Composición de Alimentos para Uso Práctico (Publicación \# 40)," Caracas, 1978 .

National Schools Public Relations Association Special Report, School Lunch Breakthrough: Politics, Technology Spur Expansion of Food Programs, 1972 . 